Check for updates

The BMJ

Cite this as: BMJ 2021;373:n1408 http://dx.doi.org/10.1136/bmj.n1408 Published: 01 June 2021

\title{
Covid-19: Government faces legal challenge over alleged suppression of school data
}

\section{Elisabeth Mahase}

The UK government could face legal proceedings unless it releases data on the spread of the Delta variant (B.1.617.2, first identified in India) of SARS-CoV-2 in England's schools, which it has been accused of suppressing.

A pre-action letter has been sent to Public Health England (PHE) by the Citizens advocacy group and the data rights agency AWO, accusing PHE of "unlawfully surrendering independent judgment" to the prime minister's office in relation to data on schools.

The move comes after the Observer reported that the prime minister's office was directly involved in a decision not to publish important data on the spread of the variant in schools, as part of a wider report. ${ }^{1}$ That report was shortly followed by the announcement that students would no longer need to wear face coverings in schools.

Before the letter, eight unions, 8o scientists, and more than 1000 parents had attempted to get the government to release the data. PHE has seven days to respond to the letter, sent on 28 May, which said that the organisation was bound by law to be independent from political interference but that it "fettered its discretion by treating the prime minister's intervention as being binding upon it." The health secretary and the prime minister are both named in the proposed claim as interested parties.

\section{"Political interference"}

Clara Maguire, executive director of the Citizens, said, "We believe that there is an immediate risk to life. The public needs this data now, and we believe that PHE is acting unlawfully in withholding it. It is unbelievable that a matter of vital importance to our public health can be subject to political interference."

The letter stated that PHE had promised stakeholders that the data would be included in reports on or around 12 May and that not publishing was therefore a "breach of a legitimate expectation." It said, "By taking into account and treating as decisive the direction of the prime minister, PHE has unlawfully taken into account an irrelevant consideration."

Deepti Gurdasani, clinical epidemiologist and senior lecturer in machine learning at Queen Mary University of London, said, "We know from media reports there are many outbreaks of the so called 'India variant' in schools, but there's no systematic data.

“In Bolton, it's risen fastest in school age children and it looks like schools are contributing to the rapid spread of the virus... and yet at this crucial moment, the government has gone ahead and lifted mitigations. It's incredibly worrying."
A PHE spokesperson told The BMJ, “A breakdown of the number of cases of each variant is published weekly. We are looking to extend this data to include information on clusters and outbreaks of variants by setting.

"Once we are happy the collection process and data are robust and quality assured, and presented in a clear format, we will publish for schools alongside other key settings as soon as possible.”

Experts have warned that the final stage of easing covid-19 restrictions, which would see all legal limits on social contact removed, should be delayed beyond 21 June owing to concerns over the Delta variant. ${ }^{2}$

1 Cadwalladr C. No 10 "tried to block" data on spread of new covid variant in English schools. Guardian 2021 May 22. https://www.theguardian.com/world/2021/may/22/no-10-tried-to-block-data-on-spreadof-new-covid-variant-in-english-schools.

2 Mahase E. Covid-19: Is it safe to lift all restrictions in England from 21 June?BMJ 2021;373:n1399. doi: 10.1136/bmj.n1399. https://www.bmj.com/content/373/bmj.n1399.

This article is made freely available for use in accordance with BMJ's website terms and conditions for the duration of the covid-19 pandemic or until otherwise determined by BMJ. You may use, download and print the article for any lawful, non-commercial purpose (including text and data mining) provided that all copyright notices and trade marks are retained. 